\title{
Hindrance as a motivation in divine guidance: The example of Paul
}

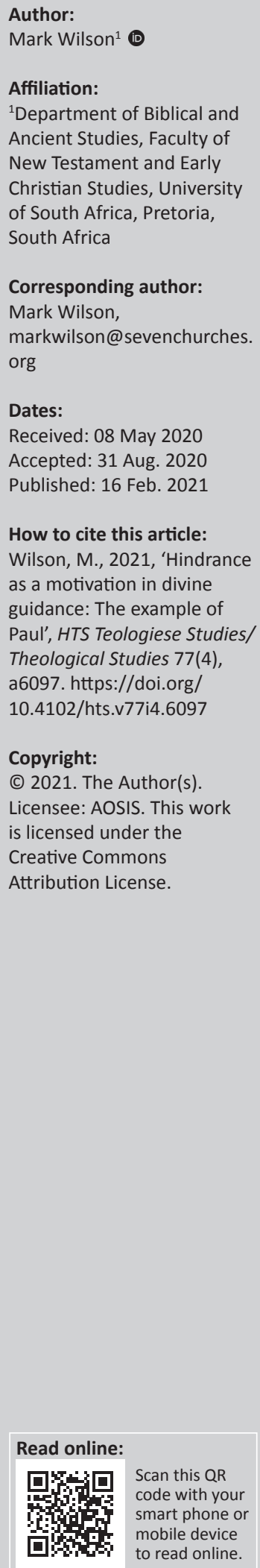

A number of factors are at work as they relate to divine guidance in the life of a Christian. Examples of odegeology - the neologism given to this dimension of practical theology - are discussed in this article around the scriptural topos of hindrance as a motivation in Paul's guidance. Four examples are considered that are drawn from the book of Acts and from his own letters. The circumstances related to these hindrances are discussed, and relevant applications are drawn from them. The article closes with a contemporary example of hindrance resulting from the coronavirus pandemic of 2019. It looks at lessons Christians are learning about the hindrances caused by this virus as they cope with restrictive stay-athome orders. These are suggested as somewhat analogous to Paul's two extended imprisonments.

Contribution: This article is the first to explore systematically all the texts regarding hindrance as a motivation for guidance related to Paul in the book of Acts and his letters. Guidance in the Christian life remains an important dimension within Practical Theology, a theological discipline within the journal's publishing tradition.

Keywords: hindrance; odegeology; Paul, Acts; ambition; imprisonment; COVID-19.

\section{Introduction}

Divine guidance is a significant issue for spiritual formation and discipleship in the life of a Christian. 'Odegeology' is the neologism given to this dimension of practical theology (cf. Wilson 2019:1, 6), and this article discusses the scriptural topos of hindrance as a motivation in divine guidance. On his second journey, Paul and his companions were hindered from preaching in Asia and Bithynia. After arriving in Troas, they then received further guidance for the next stage. Paul also mentioned hindrance in his first letter to the Thessalonians and in his letter to the Romans. However, his description of hindrance in these two pericopae is very different, and how he describes these differing motivations will be explicated. The book of Acts concludes with Paul's two extended imprisonments, yet he is portrayed as unhindered in his ministry despite confinement. This study closes with a contemporary reflection on hindrance associated with the coronavirus disease 2019 (COVID-19) pandemic. It looks at the lessons Christians are learning about the hindrances caused by this virus as they adapt to modern stay-at-home orders with accompanying restrictions on travel and church assemblies.

\section{Hindrance in Asia}

Paul, on his second journey with Silas and Timothy, was traveling westward to the province of Asia. He probably intended to establish a ministry base in Ephesus, similar to that in Antioch on the Orontes utilised for the previous 5 years (Ac 11:25-30; 12:25-13:3; 14:26-28). After revisiting the middle Galatian churches to share the report from Jerusalem, which resulted in strengthening the believers' faith (Ac 16:1-5), Paul, Silas, and Timothy were hindered by the Holy Spirit from

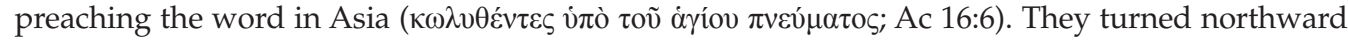
toward Bithynia, but when they neared its provincial boundary the Spirit of Jesus did not allow

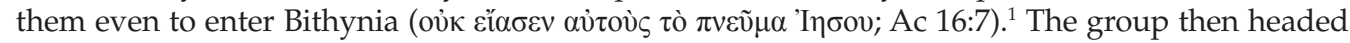
westward to the Aegean coast and arrived at the port of Alexandria Troas. ${ }^{2}$ Here, the first 'we' passage is found, and it is likely that Luke met Paul there and heard first-hand the circumstances that brought the three men to Troas (cf. Wilson 2011:361-362). So, the use of $\kappa \omega \lambda v$ w in 16:6 to describe the Spirit's hindrance might have come from Paul himself. Paul's sensitivity to divine

1. Regarding the change in language in 16:7, Barrett (1998:770) writes: 'Luke means nothing different from what he means by the Holy Spirit in v. 6. why he has a different expression is not known. He may simply have been seeking variety of expression as he makes Spirit in v. 6; why he has a different expression is not known ... He may simply have been seeking variety of expression as he makes
his unchanging assertion: the Christians did what they did under the instruction and guidance of God, who worked through his Spirit'.

2.For a further discussion of the circumstances and geography of these diversions, see Thompson and Wilson (2016:227-242); also Wilson (2020:63-66). The hindrance was for preaching, not travel, for they spent the next 4 weeks traveling approximately 800 kilometres $(\mathrm{km})$ in Asia until reaching Troas. 
guidance, first experienced on the road to Damascus, became a constant factor in his ministry travels (Wilson 2020:3-4). In this case it was the Holy Spirit or the Spirit of Jesus that hindered Paul from preaching the gospel in Asia and Bithynia. A positive consequence of the hindrance was that the gospel crossed from Asia to Europe, and the provinces of Macedonia and Achaia were reached. Paul is eventually allowed to preach in Asia, but his 3-year ministry in Ephesus does not occur until his third journey several years later (Ac 19:1-40).

\section{Hindrance in Thessalonica}

Whilst in Troas, Paul had a night vision of a Macedonian man inviting them to transit over to the Roman province of Macedonia (Ac 16:9-11). After a period of ministry and imprisonment in the Roman colony of Philippi, the apostolic party continued westward to the provincial capital of Thessalonica (Ac 16:12-40). After speaking in the synagogue there, the Jews instigated an uproar against Paul. When the mob failed to find Paul, undoubtedly concealed by local believers, they dragged Jason and some other believers before the civic officials, the politarchs. They were charged with violating the decrees of Caesar by announcing the kingdom of another emperor. Jason apparently had local connections because he and his friends were soon released on bail (Ac 17:19). The precise meaning of $\tau$ ò íavòv (bond [New International Version, NIV; New Living Translation, NLT], bail [New Revised Standard Version, NRSV; New English Translation, NET] or security [English Standard Version, ESV]) has been debated. About the adapted Latinism cum satis acceptissent, Sherwin-White (1963) has suggested that Jason:

$[I]$ s giving security for the good behaviour of his guest, and hence hastens to dispatch Paul and Silas out of the way to Beroea, where the jurisdiction of the magistrates of Thessalonica was not valid. (pp. 95-96)

At Berea, however, the Jews again caused trouble for Paul, so the local believers brought him to the coast, where he sailed for Athens. However, Silas and Timothy stayed behind (Ac 17:1015), later joining him in Athens (18:5). Upon receiving an update regarding the spiritual situation of the believers in Thessalonica (1 Th 3:6), Paul penned his first letter to the Thessalonians. Here, he mentions the reason for his inability to revisit the Thessalonians: 'because we wanted to come to you

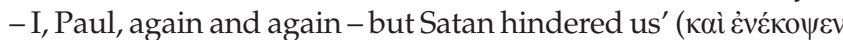

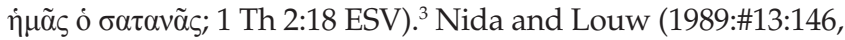

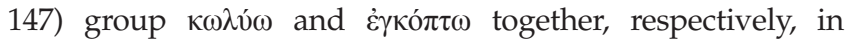
domain 13.D 'Happen'. The two verbs are thus synonyms in their limited use in the Pauline corpus (the former $4 \times$, the latter $3 \times)$. However, what exactly was the hindrance to which Paul was referring? Keener (2014) presents a likely scenario:

[W] hen Paul speaks of Satan hindering his return to Thessalonica (1 Th 2:18), he may have in mind the politarchs' decision, reported by Luke, that made his return difficult, as many scholars suggest. ${ }^{4}$ (p. 2558)

3. Referencing this verse in his discussion of Romans 1:13, Mounce $(1995: 68,268)$ suggests that 'Satanic opposition' might have been the cause of Paul's hindrance in coming to Rome. However, he abandons this interpretation in his discussion of coming to Rome.

4.Keener (2014:2558 n. 2610) lists seven scholars who concur with this view. Weima (2014:200) is more ambivalent about the specific nature of the problem and views as more important the rhetorical effect of the satanic hindrance: 'it allows Paul to
Thus, the hindrance to return to Thessalonica following the riot and subsequent restraining order was viewed by Paul as motivated by Satan. ${ }^{5}$

\section{Hindrance to visiting Rome}

Paul, after his customary prescript and greeting in Romans $1: 1-7$, tells the Romans why he is writing this letter and about his intentions to visit them in the future. In the next 10 verses of his introduction (cf. Dunn 1988a:vii), Paul uses two purpose clauses (iv $\alpha$ ) to express why he wishes to visit the Roman believers: (1) to share a spiritual gift that will strengthen them (v. 11), (2) to mutually encourage each other's faith (v. 12) and (3) to have a spiritual harvest amongst them, as with the other Gentiles (v. 13). His spiritual debt

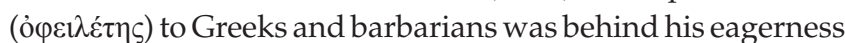
to preach the gospel in Rome. Despite all these factors motivating a visit, Paul confesses a problem that the Roman believers should be aware of: ' $[m]$ any times I desired to come

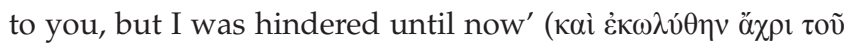
$\delta \varepsilon \tilde{v} \rho \circ ; 1: 13)$. However, the nature of that hindrance is left undeveloped in Chapter 1. Newman and Nida (1973) write:

$[T]$ he Greek is not clear as to whom or what has kept Paul from visiting the Romans, though it is possible that this is a Semitic idiom with God as the unexpressed subject. ${ }^{6}$ (p. 17)

Dunn (1988b:32) suggests that it is certainly possible that the hindrances had a demonic or satanic origin and that the expulsion of Jews from Rome by Claudius in 49 would certainly have provided a strong disincentive'. A response to Dunn is put on hold for now, with the semantics of hindrance in the Pauline vocabulary being discussed next along with whether Paul later clarified his statement in 1:13.

\section{Hindrance to arriving in Rome}

Paul's discussion of his visit to Rome forms an inclusio in Romans between the letter's opening and closing (the final Chapter 16 is largely given to personal greetings). Dunn (1988:x) begins the letter's conclusion at 15:14, whilst Witherington (2004:350) terms $15: 14-21$ as peroratio with verses $30-33$ as its pathos or emotional appeal. Interestingly, Witherington (2004:361) claims that 'one could leave out 15.22-29 and it would not be missed'. If these verses were omitted, however, the linguistic and thematic connection with Chapter 1 would be lost. For the nature of the hindrance mentioned, 1:13 is explicated more fully in 15:22: ' $[t]$ his is the

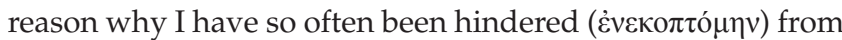
coming to you' (ESV). ${ }^{7}$ Unlike Chapter 1 , where $\kappa \omega \lambda v ́ \omega$ is

\footnotetext{
avoid personal responsibility for his failure to revisit the Thessalonian believers and thus minimizes any criticism over his ongoing absence from them'.

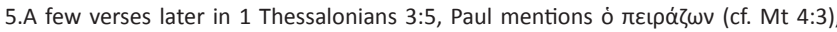
about which Bruce (1982:63) writes: ' $[t]$ he tempter is identical with Satan of 2:18, bent on frustrating the work of God by putting hindrances in the missionaries' path'.

6.No English translation has adopted this interpretation, however. Newman and Nida also fail to clarify that in Romans 15 the apostle states clearly that God is not the one hindering him.

7.The comment of Dunn (1988b:871) - ' $[t]$ he thought is clearly the same as 1:13 and almost as elusive' - is remarkable because Paul's explanation of the hindrance here is anything but elusive.
} 
found, here Paul uses its synonym غ̇үкó $\tau \omega$ (cf. 1 Th 2:18). ${ }^{8}$ Paul's interest in visiting Rome is first indicated in Acts 19:21, where, after a summary statement regarding the spread of the gospel throughout the province of Asia (19:20), Paul expressed his wish that after revisiting Macedonia, Achaia

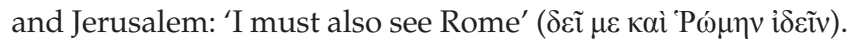
This desire was thus birthed many months, if not years, before Paul wrote his letter to the Romans. The use of $\tau \grave{\alpha}$ $\varpi 0 \lambda \lambda \alpha$ in 15:22 functions adverbially like its functional equivalent $\pi \mathrm{o} \lambda \lambda \dot{\alpha} \kappa \kappa_{\varsigma} \varsigma$ [so often or many times]. ${ }^{9}$ The fulfilment of Paul's desire to see Rome was hindered on numerous occasions by further 'open doors' of ministry in the Greek East.

The conjunctive adverb $\delta$ to introducing the sentence is rightly translated as ' $[t]$ his is the reason' (NRSV, ESV, NET) because it explains the result of a previous decision. Paul elaborated on this decision in 15:20: '[ $t$ ]hus I make it my ambition to proclaim the good news, not where Christ has already been named, so that I do not build on someone else's foundation' (NRSV). His travels from Jerusalem to Illyricum (Rm 15:19; cf. Ac 19:20) had consumed much of his time and energy to this point. Motivating these travels was an ambition to preach only in unevangelised regions. The use of the verb

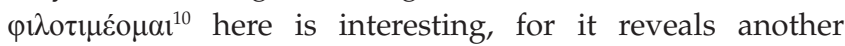
motivation for how Paul was guided in his preaching ministry. He delayed his travels to places with established Christian works whilst purposely visiting unevangelised cities and regions. ${ }^{11}$ Here 'ambition' does not have a negative sense, suggesting self-aggrandisement; rather it positively indicates his goal of enlarging the kingdom. This then was the reason for his delay in coming to Rome, where a spiritual foundation had already been laid. ${ }^{12}$ The hindrance was neither spiritual nor political but rather stemmed from personal priorities related to his ministry goals.

In Romans 15 Paul is contemplating the next stage of his public ministry. Key churches have been planted in the Greek East, thus ensuring the necessary evangelism in secondary and tertiary cities. This development has released Paul to look farther afield. The Italian peninsula is not in Paul's sights because he believes, apparently, that it is the responsibility of the believers in Rome to plant churches in their own region. ${ }^{13}$ Twice in Chapter 15, Paul mentions his new plans: a mission to Spain (vv. 24, 28) to reach the two Roman provinces on the Iberian peninsula - Hispania Citerior and Hispania Ulterior. Paul had no personal

8.Despite suggesting this possibility in their discussion of Romans $1: 13$, Newman and Nida (1973:283) now state: ' $[t]$ here is no reason for suggesting that God or the devil had prevented Paul from visiting Rome'.

9.The NLT translation 'so long' construes tà $\pi \circ \lambda \lambda \alpha$ as denoting time rather than opportunity, a less likely interpretation.

10.Only Paul uses the verb in the New Testament. In 1 Thessalonians 4:11, he urges believers to make leading a quiet life their ambition; in 2 Corinthians 5:8, the ambition of all believers should be to please Christ.

11.Paul's travel to Jerusalem with the offering from the Gentiles - the reason for his latest delay - was motivated by another ambition: to demonstrate the love and concern that the Gentile believers had for their poor brothers and sisters in Judea (cf. Rm 15:25-29).

12.For a brief discussion of Roman Christianity and the founding of the church in Rome, see Reasoner (1993:853-854).

13.This has already happened because Paul encounters believers in Puteoli when he arrives in Italy (Ac 28:13-14). hindrance to this planned mission because it fit his twofold ambition: to preach where Christ had not been heralded and not to build on the foundation of anyone else. Whilst another hindrance from the Spirit might arise during his journey, such an adjustment would only be a course correction. Nevertheless, Paul perceived a possible political hindrance so he asked the Romans to intercede for him in a particular way: ' $p$ ]ray that I will be rescued from those in Judea who refuse to obey God' (Rm 15:31 NLT). Paul had previously asked the Thessalonians to pray for his deliverance from his enemies in Corinth (2 Th 3:2) ${ }^{14}$ And later Paul told the Ephesian elders in Miletus that the Spirit was warning him that trials and persecution lay ahead in Judea and that he would never see their faces again. They seemingly interpreted this as Paul's impending martyrdom (Ac 20:23-38). Thus, when Paul was writing to the Romans from Corinth, he seems to anticipate opposition upon his arrival in Jerusalem. The readers of Acts are presented the specifics of that opposition in Chapters 21-22 when Paul is arrested at the temple, incarcerated briefly in the Antonia Fortress and then transferred to Caesarea Maritima. This setback proved to be yet another hindrance regarding Paul's ambition to reach Rome.

\section{Without hindrance in Caesarea and Rome}

The book of Acts concludes with two extended pericopae describing Paul's 2-year imprisonments both in Caesarea and Rome (Ac 23:33-28:31). In Caesarea he was confined to Herod's praetorium and chained to a centurion (Ac 23:35; 26:29). ${ }^{15}$ Yet within this confinement Felix ordered that Paul should have some freedom and that no one should hinder ( $\left.\omega \lambda v_{\varepsilon} \varepsilon v\right)$ his friends from supplying Paul's physical needs (Ac 24:23). To hinder, according to Rapske (1994:171), ${ }^{16}$ 'in this context probably denotes restricting access to the prisoner, whether out of duty or animosity'. Because prisoners did not become a ward of the Roman state, family or friends needed to bring them food and clothing. ${ }^{17}$

Paul's stay in the praetorium ended with his appeal to Caesar, and soon he was en route to Rome again in the custody of a centurion (Ac 26:32-27:1). Surviving a shipwreck and a rescue on Malta, Paul finally arrived in Rome (Ac 28:16-31). There he was allowed to procure lodging for himself, where he received leaders from the Jewish community (28:16-29). ${ }^{18}$ For 2 years he welcomed visitors, evangelising and teaching about Jesus Christ. Although still chained to a soldier 14.2 Timothy 3:11 mentions how Paul was rescued from his persecutors in Galatia.

15.For a discussion of how Herod's Palace served as a residence, headquarters and praetorium for Rome in Paul's day, see Netzer (2008:106-111). Paul's confinement was probably in quarters in the Upper Palace.

16.For a fuller description of Paul's house arrest in Caesarea, see Rapske (1994:167172).

17.Paul did have a sister and a nephew in Jerusalem who might have been involved in his care (Ac 23:16).

18.For a discussion about these arrangements, see Rapske (1994:177-180), who further notes that 'Paul's custody in Rome is the least severe of all the imprisonments Luke reports' (182). 
(Ac 28:16, 20), ${ }^{19}$ his demeanour is characterised as bold and 'unhindered' ( $\dot{\alpha} \kappa \omega \lambda v \tau_{\omega} \omega \xi$ v. 31). This, the final word in Acts, is also translated 'without hindrance' (cf. NRSV, NIV). According to Wall (2002):

[L]uke places akōlytōs in the emphatic position at the end of his book not merely to characterize Paul's imprisonment as allowing him considerable personal freedom but also to characterize the unhindered and unstoppable spread of God's gospel according to God's purposes. ${ }^{20}$ (p. 368)

Although Wall (1992a:120) argues that there is no indication that the author of Acts knew the letters of Paul, Luke seemingly knows Paul's letter to the Romans, for the ending of Acts provides an intertextual commentary, albeit brief, to the book of Romans, which follows. As seen in the introduction to Romans, Paul declared how he had intended to visit Rome for many years, but his plan had been hindered

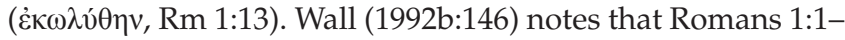
15 has a particular interest for canonical critics 'since it lies at the seam between Acts and the New Testament letter collections and gives definition to the final form of the biblical canon'. Whilst Wall (1992b:148-155) goes on to claim rightly a much broader function for the opening verses of Romans, our interest is much narrower. The New Testament reader understands from the end of Acts that Paul did preach the gospel in Rome 'unhindered', ${ }^{21}$ before reading in Romans that Paul was 'hindered' for a considerable time from preaching and teaching the word there. Thus, the sense of expectation and uncertainty experienced by the first audience of Romans is resolved for canonical readers of these two books, for the conclusion of Acts has already presented the paradox of the chained apostle preaching without hindrance in Rome.

\section{Hindrance as a motivation during the coronavirus 2019 pandemic}

Christians today are experiencing another type of hindrance never encountered by Paul: that caused by the coronavirus pandemic. Every aspect of normal life has changed for people around the world: work, travel, education, shopping, entertainment and so on. Schedules have been altered, and conferences and trips cancelled or postponed. Governments around the world have implemented lockdown measures to impede the transmission of the virus and thus minimise infections and the loss of life. Churches have been hindered from holding public gatherings and instead are conducting services online using the various digital platforms now available. For months our international church in Antalya, Turkey, conducted all its worship services and prayer

19.Seneca (EP 5.7) analogises, "[j]ust as the same chain fastens the prisoner and the soldier who guards him ...'

20.Rapske (1994:182) suggests that 'unhindered' indicates both the Roman tolerance of Paul's religious activities and the official leniency accorded by the soldier guarding him.

21.Parsons (2008:672), quoting Stagg and Pervo, believes that this final word sums up the message of Acts vis-à-vis the preaching of the gospel. He writes, ' $t]$ he gospel is unhindered because of the sovereignty of God who ultimately ensures its triumph in the face of adversity'. meetings online. A young couple in our congregation was engaged to be married but could not obtain a marriage license locally because the office had closed. This hindrance forced them to be married online in a civil ceremony presided over by an official far away in the US state of Utah. Our pastor later conducted their religious ceremony, witnessed by over 100 family members and friends around the world, connected via Zoom. Such workarounds became the 'new normal' for churches around the world.

Perhaps our situation during the COVID-19 pandemic has more parallels with the hindrances experienced by Paul than may initially be thought. The stay-at-home orders and total lockdowns experienced by Christians worldwide are somewhat analogous to Paul's prolonged imprisonments. Even as Paul could receive guests and visitors, we host friends and family virtually in our residences through Skype and FaceTime. However, our confinement pales in comparison to what the apostle experienced both in length and conditions - a chain continually chafing his wrist, iron rattling when he rustled in bed, the same four walls staring back monotonously, and blue sky on the open road and moonlight on a glassy sea only a distant memory. Pondering the stress and anxiety that the hindrances related to this pandemic have produced in our lives, we should have more of an existential empathy with Paul and his experience of 4 long years of stay-at-praetorium in Caesarea and stay-athome in Rome.

\section{Conclusion}

In the conclusion of my volume The Spirit Said Go, the 22 examples of guidance given to Paul in Acts are organised into three categories: supernatural, volitional and providential (Wilson 2020:147). The hindrance against preaching in Asia is placed in the supernatural category. Paul's aspirational hindrance that delayed his visit to Rome, though not discussed in the book, would fall into the volitional category. However, the hindrance posed by Satan does not find an equivalent in Acts. Perhaps the closest example was the adversity experienced by Paul and Barnabas when they were driven from Pisidian Antioch and Iconium, and then Paul's stoning in Lystra (Ac 13:50-14:19). The trauma to Paul likely resulted in impaired vision and a possible concussion and should be connected to the 'messenger of Satan', who incited the hardships and persecutions mentioned in 2 Corinthians 12:7-10.22 Thus, a connection may exist between the satanic hindrance effected by political and religious opponents both in Galatia and later in Macedonia.

Summarising the motivation of hindrance as guidance in Paul's ministry, we see four outcomes:

1. The Holy Spirit hinders Paul from preaching in one place to get him to a more strategic location. Timing is an important factor in evangelism, and the Holy Spirit knows the times and seasons when ministry will be

22. Such a connection is suggested by this comment by Harris (2005:867). "Behind $\dot{\alpha} \sigma \theta \varepsilon v \tilde{\omega}$ we should probably see an allusion to the physical debility brought about do $z$ av w we shou probably se an allusion to the physical debility brought about dis encountered during his service for Christ, circumstances such as "insults, calamities, persecutions and difficulties" (cf. v. 10a) that prompted a sense of helplessness and drove him to turn to Christ in prayer'. 
most effective. Ephesus could wait until later, whilst establishing churches in Macedonia and Achaia was strategically more important for this phase of Paul's ministry.

2. Satan sometimes puts up hindrances to impede ministry. Civic authorities prevented Paul from remaining in Thessalonica and thus curtailed personal contact with the believers there. As is known, political and governmental opposition continues to hinder the gospel's proclamation in some countries. Because Paul could not revisit Thessalonica, he was forced to write two letters to the Thessalonian church. These became part of the New Testament canon. Thus, Satan's hindrance, in a spiritual reversal, has accrued to the edification of Christians, who have been reading these letters for the past 2000 years.

3. Paul's hindrance in visiting Rome is a bit surprising: his own ambition related to preaching the gospel. The Holy Spirit had given him a particular goal - to plant churches throughout the eastern Mediterranean. In Romans 15:23 he makes the astonishing statement: ' $[b]$ ut now that there is no more place for me to work in these regions'. No more place to evangelise surely seems a Pauline hyperbolism. However, in his thinking a beachhead for the gospel had been established throughout Syria, Asia Minor, Macedonia, Achaia and Illyricum. Now he could move westward to Spain, using Rome as his jumping-off point. Whether Paul's ambition to reach Spain was achieved is beyond the scope of this article, although the likelihood is high that such a journey occurred.

4. Paul's extended confinements in Caesarea and Rome present a remarkable irony within the topos of hindrance. Despite the limitation of his freedom, Luke presents the apostle as unhindered in both. In Caesarea his friends had unhindered access to him. And Jesus' promise at Paul's conversion that he would appear before kings (Ac 9:15) is finally fulfilled with his appearances before Felix, Festus and Agrippa. Although chained throughout his 2-year house arrest in Rome, Paul's ministry to his visitors continued unhindered. In conclusion, this study has demonstrated that hindrance as portrayed in Acts and Romans was a significant motivation for guidance in Paul's life and ministry.

\section{Acknowledgements Competing interests}

The author declares that he has no financial or personal relationships that may have inappropriately influenced him in writing this article.

\section{Author's contribution}

M.W. is the sole contributor to this research article.

\section{Ethical considerations}

This article followed all ethical standards for carrying out research without direct contact with human or animal subjects.

\section{Funding information}

This research received no specific grant from any funding agency in the public, commercial or not-for-profit sectors.

\section{Data availability}

Data sharing is not applicable to this article as no new data were created or analysed in this study.

\section{Disclaimer}

The views and opinions expressed in this article are those of the author and do not necessarily reflect the official policy or position of any affiliated agency of the author.

\section{References}

Barrett, C.K., 1998, Acts 15-28, T\&T Clark, London.

Bruce, F.F., 1982, 1 \& Thessalonians, Word, Dallas, TX.

Dunn, J.D.G., 1988a, Romans 1-8, Word, Dallas, TX.

Dunn, J.D.G., 1988b, Romans 9-16, Word, Dallas, TX.

Harris, M.J., 2005, The second epistle to the Corinthians: A commentary on the Greek text, Eerdmans, Grand Rapids, MI.

Keener, C.S., 2014, Acts 15:1-23:35, An exegetical commentary, vol. 3, Baker, Grand Rapids, MI.

Mounce, R.H., 1995, Romans, Broadman \& Holman, Nashville, TN.

Netzer, E., 2008, The architecture of Herod, the great builder, Baker, Grand Rapids, MI. Newman, B.M., \& Nida, E.A., 1973, A translator's handbook on Paul's letter to the Romans, United Bible Societies, New York, NY.

Nida, E.A. \& Louw, J.P., 1989, Greek-English lexicon of the New Testament, 2nd edn., 2 vols., American Bible Society, New York, NY.

Parsons, M.C., 2008, Acts, Baker, Grand Rapids, MI.

Rapske, B., 1994, The book of Acts and Paul in Roman custody, in The book of Acts in its first century setting, vol. 3, Eerdmans, Grand Rapids, MI.

Reasoner, M., 1993, 'Rome and Roman Christianity', in G.F. Hawthorne \& R.P. Martin (eds.), Dictionary of Paul and his letters, pp. 850-855, InterVarsity, Downers Grove, IL.

Sherwin-White, A.N., 1963, Roman society and Roman law in the New Testament, Oxford University Press, Oxford.

Thompson, G.L. \& Wilson, M., 2016, 'The route of Paul's second journey in Asia Minor: In the steps of Robert Jewett and beyond', Tyndale Bulletin 67(2), 217-246.

Wall, R.W., 1992a, 'The Acts of the apostles in canonical context', in R.W. Wall \& E.E. Lemcio (eds.), The New Testament as canon: A reader in canonical criticism, pp. 110-128, Sheffield Academic Press, Sheffield.

Wall, R.W., 1992b, 'Romans 1.1-15: An introduction to the Pauline corpus of the New Testament', in R.W. Wall \& E.E. Lemcio (eds.), The New Testament as canon: A reader in canonical criticism, pp. 142-160, JSOT, Sheffield.
restat.

Wall, R.W., 2002, 'The Acts of the Apostles', in L.E. Keck (ed.), The New Interpreter's Bible: Ac; Introduction to Epistolary Literature; Romans; 1 Corinthians, vol. 10, pp. 3-370, Abingdon, Nashville, TN.

Weima, J.A.D., 2014, 1-2 Thessalonians, Baker, Grand Rapids, MI.

Wilson, M., 2011, 'Review of The "we" passages in the Acts of the apostles by William Sanger Campbell', Neotestamentica 45(2), 360-362.

Wilson, M., 2019, 'Praxeis as praxis: Odegeology as practical theology in the book of Acts', HTS Theological Studies 75(2), 1-7. https://doi.org/10.4102/hts.v75i2.5416

Wilson, M., 2020, The Spirit said go: Lessons in guidance from Paul's journeys, rev. edn., Wipf \& Stock, Eugene, OR.

Witherington, III, B., 2004, Paul's letter to the Romans: A socio-rhetorical commentary, Eerdmans, Grand Rapids, MI. 